\title{
FORMULASI PAKAN LENGKAP UNTUK PEMBESARAN BENIH LELE (Clarias batrachus)
}

\author{
I Nengah Sweta Rabegnatar") dan Evi Tahapari")
}

\begin{abstract}
ABSTRAK
Untuk mendukung pengembangan budi daya lele secara intensif dan komersial perlu diketahui formulasi pakan buatan yang lengkap secara nutrisi bagi benih lele. Tujuan penelitian ini adalah menemukan formulasi pakan yang lengkap dan ekonomis bagi benih lele. Data mutu dan uji beda nyata dari enam pakan perlakuan dengan formulasi berbeda dievaluasi pada akhir percobaan pemberian pakan dengan benih lele berukuran awal rata-rata $2,21 \pm 0,06 \mathrm{~g}$ pada lele yang diberi pakan sejumlah 10\%-6\% dari bobot tubuh/hari selama 53 hari. Pakan perlakuan adalah A (44,05\% protein); B (33,73\% protein); C (33,52\% protein) yang didesain sebagai pakan lengkap; D (37,87\% protein) yang dibedakan dari B dengan peniadaan bahan minyak esensial, mineral, dan vitamin dari formulasinya; serta dua pakan komersial $E(47,34 \%$ protein) dan $F$ $(47,31 \%$ protein). Semua pakan menghasilkan ikan dengan morfologi normal, pertambahan bobot rata-rata, peningkatan kadar protein, abu, dan lemak serta penurunan kadar air dan karbohidrat tubuh dibanding sebelum pemberian pakan. Pakan A bermutu tertinggi di antara ke6 pakan sedangkan pakan D terendah mutunya. Dibanding kedua pakan komersial, pakan A lebih tinggi $(P<0,05)$ dalam hal pertambahan bobot rata-rata serta lebih tinggi, atau sama dalam hal kadar protein tubuh dan efisiensi pakan. Pakan $C$ lebih tinggi atau sama dalam hal pertambahan bobot rata-rata dan kadar protein tubuh. Pakan D sama atau lebih rendah dalarn hal pertambahan bobot rata-rata, kadar protein tubuh dan efisiensi pakan. Sintasan benih pada pakan A tidak berbeda nyata dengan pakan komersial, di mana bagi pakan B, C, D lebih rendah; tetapi kematian benih berkorelasi nyata $(P<0,05)$ dengan kadar $\mathrm{NH}_{3}$ dalam air, yang dalam praktek dapat dihindari.
\end{abstract}

\section{ABSTRACT: Complete feed formulation for rearing walking catfish fry (Clarias batrachus). By: I Nengah Sweta Rabegnatar and Evi Tahapari}

In order to support the development of intensive and commercial cuiture of walking catfish, it is necessary to find a nutritionally complete artificial feed for the fry. The objective of this research was to find an economical, nutritionally complete artificial feed formulation for rearing walking catfish. Feed quality data of six diets of different formulations and their significance differences were evaluated after completion of a feeding experiment in which the walking catfish fry averaging $2.21 \pm 0.05 \mathrm{~g}$ in initial individual weight were fed at daily feeding rates of $10 \%-6 \%$ of body weight for 53 days. The six different diets were A ( $44.04 \%$ protein), B (38.73\% protein), C (33.52\% protein) designed as complete diets, $D$ (38.87\% protein) differing from $B$ in its formulation which did not contain added essensial oils, minerals and vitamins; and two commercial diets E $(47.34 \%$ protein) and $F(47.31 \%$ protein). All diets produced fish with normal morphology, individual weight gain (IWG), increase in body protein (BP), ash and lipids contents and decrease in body moisture and carbohydrate content compared to those prior to feeding. Diet $A$ had the highest quality of all six diets, which diet $D$ the lowest. Compared to the commercial diets, $\operatorname{diet} A$ was and superior $(P<$ 0.05) in IWG, superior or similar in feed efficiency (FE) and BP content, and similar in other components of the fish proximate composition. By the same comparison, diet $B$ was superior or similar in IWG and FE, diet $C$ was superior or similar in IWG and BP content, while diet $D$ was similar or inferior in IWG, FE and BP content. The fry survival rate of diet $A$ was not significantly different compared to the commercial diets. Those of diets $A, B, C$ were lower, but the mortalities were significantly correlated $(P<0.05)$ to $\mathrm{NH}_{3}$ contents of the water, which can be avoided in future practices.

KEYWORDS: fish, feed formulation, Clarias batrachus, fry

\section{PENDAHULUAN}

Penelitian ini merupakan lanjutan dari rangkaian penelitian yang dilakukan sebelumnya dalam upaya menemukan formulasi pakan buatan yang bermutu tinggi, efisien, dan ramah lingkungan untuk pembesaran benih lele. Pakan adalah komponen amat penting dari teknologi budi daya ikan. Formulasi pakan disusun dengan berpedoman pada kebutuhan nutrien dan energi ikan terkait serta mutu bahan pakan.

") Peneliti pada Balai Penelitian Perikanan Air Tawar, Sukamandi 
Sebelumnya telah diperoleh informasi pertumbuhan benih lele yang diberi pakan buatan (Rabegnatar et al.,1990) dan pakan dengan kadar protein dan energi berbeda (Suhenda, 1988); kebutuhan tambahan campuran vitamin dalam pakan buatan (Rabegnatar et al.,1991 a,b); perbandingan optimal energi dan protein pakan buatan (Rabegnatar \& Hidayat, 1992). Kadar optimal protein dalam pakan buatan (Rabegnatar \& Asih, 1995); dan kebutuhan kadar minyak ikan dan minyak jagung sebagai sumber asam lemak esensial dan pemakaian minyak kelapa dalam pakan buatan (Rabegnatar \& Praseno, 1993). Meskipun belum terdapat informasi khusus kebutuhan tiap jenis vitamin dan mineral bagi benih lele, namun informasi yang ada ini serta informasi mineral dalam pakan penelitian sebelumnya merupakan pedoman penting penyusunan formulasi pakan lengkap yang bermutu tinggi dan efisien bagi benih lele. Formulasi pakan harus disusun dari bahan pakan sumber protein dan energi yang disukai, mudah dicerna benih, dan pakan secara keseluruhan (pelet, krambel) harus dapat memenuhi kebutuhan nutrien benih.

Tujuan penelitian ini adalah untuk menemukan formulasi pakan lengkap yang bermutu tinggi dan efisien bagi benih lele berukuran sekitar $2 \mathrm{~g}$.

\section{BAHAN DAN METODE}

Percobaan pemberian pakan berbeda pada benih lele dilakukan secara terkontrol dalam kondisi laboratorium. Percobaan menggunakan 6 jenis pakan dengan formulasi berbeda yaitu 4 jenis pakan laboratorium dan dua jenis pakan komersial. Pada akhir percobaan diidentifikasi pakan laboratorium yang bermutu terbaik serta dinilai perbandingan dengan kedua pakan komersial. Percobaan memakai Rancangan Acak Lengkap dengan 6 perlakuan pakan dan 3 ulangan. Hipotesis yang diuji ialah bahwa pakan dari formulasi yang berbeda menghasilkan pertumbuhan dan komposisi proksimat tubuh benih lele yang berbeda.

Benih lele yang digunakan berukuran rata-rata $2,21 \pm 0,06 \mathrm{~g}$, ditebar dengan kepadatan 50 ekor per akuarium $(50 \mathrm{~L})$ atau 50 ekor/0,02 $\mathrm{m}^{2}$.

Keenam pakan perlakuan terdiri atas empat jenis pakan laboratorium yakni $A, B, C$ yang didesain sebagai pakan lengkap dan $D$ yang dibedakan dari $B$ dengan peniadaan bahan minyak sumber asam lemak esensial, mineral, dan vitamin dalam formulasinya; dengan kadar protein berbeda \% dari campuran bahan pakan; A (45\%), B (40\%), C (35\%), D (40\%) atau dengan kadar protein, \% dari krambel: A $(44,04 \%)$; B $(38,73 \%) ; \mathrm{C}(33,52 \%) ; \mathrm{D}(38,87 \%)$; dan kedua pakan komersial E $(47,34 \%$ protein); serta F $(47,31 \%$ protein).
Pakan A, B, C, D dibuat dari bahan yang biasa dimakan benih lele dan telah digunakan dalam penelitian sebelumnya yakni tepung ikan, tepung kedelai, dedak, dan (kecuali D) minyak ikan (asam lemak esensial omega- ${ }^{3}$ ), minyak jagung (asam lemak esensial omega- ${ }^{6}$ ), minyak kelapa (sumber energi), berbagai mineral, dan berbagai vitamin (Lampiran 1, 2, 3, dan 4). Formulasi nutrien dan energi benih lele seperti dikemukakan pada bagian pendahuluan dan dengan mempertimbangkan komposisi proksimat tepung ikan, tepung kedelai, dan dedak. Dalam keempat pakan laboratorium, perbandingan protein tepung ikan dan protein tepung kedelai adalah optimal yakni 3,37:1 (Rabegnatar \& Asih, 1995).

Kadar protein asal dedak dalam pakan B dan D adalah 2,5\%; dalam pakan C 3,5\%. Jumlah pakan harian yang diperkirakan menghasilkan laju pertumbuhan tinggi dan disesuaikan dengan upaya pencegahan memburuknya kualitas air media, yakni sejumlah: a) dalam periode kesatu (19 hari): 10\%-8\% dari bobot total awal benih, b) dalam periode kedua (14 hari): $8 \%-6 \%$ dari bobot benih akhir periode kesatu, c) dalam periode ketiga atau terakhir (20 hari): $7 \%$ dari bobot benih akhir periode kedua. Pakan diberikan dua kali sehari pada pukul 08.30 dan12.30 tiap kali sebanyak 0,5 bagian dari jumlah pakan harian. Benih yang mati segera dikeluarkan dari akuarium dan jumlah pakan harian disesuaikan dengan bobot benih yang hidup bila kematian terjadi dalam waktu kurang dari seminggu setelah penimbangan berkala bobot total benih dalam akuarium. Air media akuarium diaerasi selama percobaan dan diganti tiap sore sebanyak $2 /$ 3 volumenya dengan air dari bak penampungan dan juga diaerasi. Air media yang digunakan sejak awal percobaan berasal dari sumur yang sama, diaerasi dan diaklimatisasi, serta dalam periode aklimatisasi benih, mendukung kehidupan normal benih. Kualitas air ini disesuaikan dengan anjuran Boyd (1979).

Penimbangan bobot total benih dalam tiap akuarium dilakukan pada awal percobaan dan pada akhir periode kesatu, kedua, dan ketiga. Nilai konversi pakan relatif dihitung pada akhir percobaan. Kadar protein serta komposisi proksimat tubuh benih dianalisis pada awal dan akhir percobaan. Sintasan benih dan pengamatan kondisi fisik benih dilakukan pada akhir percobaan. Kualitas air diukur sebelum percobaan dan dalam tiap periode pemberian pakan. Pada akhir percobaan dilakukan analisis beda nyata pertambahan bobot, kadar protein, dan komponen proksimat tubuh lainnya serta nilai konversi pakan relatif berdasar uji DNMRT (Duncan'S New Multiple Range Test) setelah mempertimbangkan kebutuhan formasi data seperti diuraikan oleh Shell (1983), Sokal \& Rohlf (1973), dan Steel \& Torrie (1960). Urutan mutu pakan ditetapkan berdasarkan kriteria pertambahan 
bobot rata-rata serta kadar protein tubuh benih lele dan nilai konversi pakan atau efisiensi pakan (efisiensi pakan kebalikan nilai konversi pakan). Data parameter benih yang lain merupakan data penunjang dan deskriptif.

\section{HASIL DAN BAHASAN}

\section{Sintasan Benih Lele}

Ditinjau dari pengaruh langsung pakan sebagai nutrien dan dalam kondisi optimal khususnya kualitas air, maka hipotesis yang diuji ialah bahwa sintasan antar perlakuan pakan tidak berbeda nyata dan sekitar $100 \%$ (dalam kisaran pengaruh faktor acak) sebab pakan terbuat dari bahan yang biasa dimakan benih lele. Asumsi demikian dapat diterima pula dalam hal pakan komersial. Data sintasan pada Tabel 1, menunjukkan beda nyata $(P<0,05)$ antara beberapa
$\mathrm{NH}_{3}$ dalam periode pemberian pakan ke-1 (sebelum penimbangan benih lele) dengan nilai r dalam selang kepercayaan $95 \%$ berkisar antara -0,9999 sampai 0,4761 tetapi korelasi sintasan dengan kadar $\mathrm{NH}_{3}$ dalam periode selanjutnya tidak nyata. $\mathrm{Kadar} \mathrm{NH}_{3}$ dalam periode kesatu lebih tinggi dari yang dalam periode selanjutnya, hal ini sejalan dengan perubahan jumlah pemberian pakan (Lampiran 7). Dalam periode ke-1 bagi pakan laboratorium (A,B,C,D) yakni 1,07$3,33 \mathrm{mg} / \mathrm{L}$ ternyata juga melampaui kisaran kadaryang mematikan $50 \%$ lele Amerika tersebut di atas. Sebaliknya kadar $\mathrm{NH}_{3}$ bagi kedua pakan komersial $\mathrm{E}$ dan $\mathrm{F}$ lebih rendah yakni $0,42 \%-0,73 \%$ dengan kematian benih lele nol sampai $0,7 \%$. Tampaknya kematian benih ini hanya akibat faktor acak. Kadar protein kedua pakan komersial lebih tinggi dari pakan laboratorium (Lampiran 2). Jadi mungkin kedua pakan ini mengandung senyawaan yang dapat menyerap $\mathrm{NH}_{3}$ seperti dikemukakan Akiyama (1991) dan senyawaan

Tabel 1. Sintasan, bobot, dan pertambahan bobot benih setelah 53 hari pemberian pakan

Table 1. Survival rates, body weight, and body weight gains of the fish after 53 days of feeding

\begin{tabular}{|c|c|c|c|}
\hline $\begin{array}{l}\text { Pakan } \\
\text { Diets }\end{array}$ & $\begin{array}{l}\text { Sintasan (\%) } \\
\text { Survival rate (\%) }\end{array}$ & $\begin{array}{l}\text { Bobot }(g) \\
\text { Weight }(g)\end{array}$ & $\begin{array}{c}\text { Pertambahan bobot (\%/hari) * } \\
\text { Body weight gains (\%/days) }\end{array}$ \\
\hline A & $87.33 \pm 14.47^{a b^{* *}}$ & $14.24 \pm 1.58$ & $10.56 \pm 1.47^{a^{* *}}$ \\
\hline $\mathrm{B}$ & $71.33 \pm 15.01^{b c}$ & $8.49 \pm 1.05$ & $5.41 \pm 0.86^{b}$ \\
\hline $\mathrm{C}$ & $50.67 \pm 7.02^{c}$ & $6.31 \pm 0.71$ & $3.46 \pm 0.55^{\mathrm{cd}}$ \\
\hline $\mathrm{D}$ & $61.33 \pm 33.25^{b c}$ & $5.74 \pm 0.38$ & $2.96 \pm 0.46^{d t}$ \\
\hline$E$ & $100.00 \pm 00^{a}$ & $7.53 \pm 0.64$ & $4.54 \pm 0.35^{b c}$ \\
\hline $\mathrm{F}$ & $99.33 \pm 1.15^{a}$ & $4.37 \pm 0.03$ & $1.84 \pm 0.06^{f}$ \\
\hline
\end{tabular}

* Nilai rataan dan simpangan baku (Mean and standard deviation)

**Nilai dalam kolom yang sama dan diikuti oleh huruf yang sama tidak berbeda nyata $(P>0,01)$

Value in columns followed by the same superscript are not significanly different $(P>0.01)$

pakan yakni antara $A$ dan $C$; serta antara $B, C, D, E$, dan $F$ yang sintasannya tertinggi sedangkan pasangan pakan lainnya tidak berbeda nyata $(A, E$, dan F). Beda nyata ini tidak disebabkan oleh pengaruh langsung pakan sebagai nutrien melainkan pengaruh tak langsung yang bersifat sementara sebagai akibat perubahan sekunder melalui perubahan kualitas air khususnya dengan terbentuknya senyawa amonia tak terionisasi $\left(\mathrm{NH}_{3}\right)$ dalam air media. Senyawa $\mathrm{NH}_{3}$ pada kadar, jangka waktu, dan kondisi tertentu mematikan ikan; misalnya bagi ikan umumnya kadar $3,8 \mathrm{mg} \mathrm{NH}_{3} /$ mematikan dalam jangka pendek, dan bagi jenis lele iklim panas Amerika "channel catfish" (Ichtalurus punctatus) kadar 0,6-2 $\mathrm{mg} \mathrm{NH}_{3} / \mathrm{L}$ mematikan $50 \%$ ikan ini dalam 96 jam pada suhu $30^{\circ} \mathrm{C}$ (Boyd, 1979) dan kadar $2,5 \mathrm{mg} / \mathrm{L}$ mematikan ikan ini pada keadaan umumnya. Data sintasan benih lele (Tabel 1) ternyata mempunyai korelasi negatif yang nyata dengan kadar pencegah stres benih ikan. Dalam percobaan ini maupun percobaan sebelumnya sintasan benih ikan pada penimbangan akhir periode pertama selalu tinggi (hampir $100 \%$ ) sesudah itu terjadi kematian mencolok. Dalam percobaan ini kematian benih yang mencolok terjadi dalam masa awal periode kedua saja, jadi kadar $\mathrm{NH}_{3}$ dalam periode kesatu termasuk kadar yang akan mematikan dalam waktu relatif lama dan masih dibutuhkan faktor stres penimbangan untuk terjadinya kematian benih lele kurang dari $50 \%$ (sintasan lebih dari $50 \%$ ).

Dengan demikian, beda nyata sintasan antara pakan ini hanyalah akibat perubahan sekunder yang dialami pakan dan bersifat tidak tetap dan dapat dihindari dalam praktek. Dalam hal ini diperkirakan kadar air media yang kualitasnya optimal, diperkirakan sintasan benih pada semua pakan sekitar $100 \%$. 
Korelasi antara variasi sintasan antara pakan ini dan variasi pertambahan bobot benih lele terkait tidak nyata $(P>0,05)$. Ini merupakan konfirmasi bahwa beda nyata parameter benih antara pakan tetap hanya mewakili beda pengaruh pakan (tidak terdapat faktor perbedaan padat tebar benih).

\section{Pertambahan Bobot Rata-Rata, Nilai \\ Konversi Pakan, Kadar Protein, serta Komposisi Proksimat Tubuh Benih Lele}

Keenam pakan perlakuan meningkatkan ukuran rata-rata benih lele. Pertambahan bobot rata-rata pada pakan laboratorium A, B, C, D berkisar 2,96\% (D) sampai dengan 10,56\%/hari (A); atau ukuran bobot benih dalam 53 hari menjadi 2,57 sampai 66,60 kali semula dan pertambahan bobot rata-rata untuk pakan komersial E dan F masing-masing 4,54\% dan 1,64\%/ hari atau ukuran bobot benih dalam 53 hari menjadi 1,98 dan 3,41 kali semula (Tabel 1). Peningkatan bobot benih disertai perubahan komposisi proksimat benih (Lampiran 5 dan 6). Dibanding sebelum diberi pakan terjadi peningkatan kadar protein, mineral (abu) dan lemak tubuh, dan penurunan kadar protein, mineral karbohidrat tubuh, peningkatan ukuran dan perubahan komposisi. Kadar protein tubuh cukup tinggi yakni $13,39 \%$ (D) sampai dengan 14,34\% (A) bagi pakan A, B, C, D dan bagi kedua pakan komersial $14,07 \%$ (E) dan $14,80 \%(F)$; dibanding dengan kadar protein benih sebelum diberi pakan (12,13\%) dan dibanding protein sel tubuh hewan umumnya 12\%-14\% (Strand, 1976). Nilai konversi pakan (Tabel 2) bagi pakan A,B,C,D berkisar 1,70 (A); 5,60 (D) dan bagi pakan komersial 2,68 (E); dan 5,30 (F).

Telah dibahas dimuka bahwa variasi sintasan dan variasi kadar $\mathrm{NH}_{3}$ dalam air media tidak berpengaruh pada hasil uji beda nyata data parameter benih antara pakan (pertambahan bobot rata-rata, efisiensi pakan atau nilai konversi pakan, dan komposisi proksimat benih).

\section{Pertambahan Bobot Rata-Rata Benih Lele}

Pakan A menghasilkan pertambahan bobot ratarata tertinggi $(P<0,05)$ di antara keenam pakan (Tabel 1). Urutan kemampuan pakan laboratorium menghasilkan pertambahan bobot rata-rata dari yang tertinggi ke yang terendah (yang dalam kurung tak berbeda nyata). Pertambahan bobot rata-rata pakan $\mathrm{A}$ mencolok lebih tinggi dari semua pakan lain karena kadar protein dan perbandingan energi metabolisme dan proteinnya optimal. Kadar protein optimal pakan benih lele adalah sekitar $45,38 \%$ dalam campuran bahan (Rabegnatar \& Praseno, 1993) sedang perbandingan optimal energi dan protein untuk pertambahan bobot rata-rata adalah 7,34 kkal/g protein (Rabegnatar \& Hidayat, 1992).
Pertambahan bobot rata-rata keempat pakan laboratorium ini sesuai dengan rancangan komposisi pakan dan prinsip nutrisi bahwa peningkatan kadar protein pakan sampai batas kadar protein optimal (dalam A,B,C) meningkatkan pertambahan bobot ratarata. Sedang ketidakcukupan nutrien khususnya nutrien esensial ( $B$ dibanding $D)$, minyak kelapa, mineral dan campuran vitamin dalam ramuan bahan pakan D, mengurangi kadar asam lemak esensial, mineral, vitamin, dan juga energi pakan D. Akibatnya ternyata juga mengurangi pertambahan bobot rata-rata sampai pertambahan bobot rata-ratanya tidak berbeda nyata dengan pakan $\mathrm{C}$, padahal kadar protein pakan $\mathrm{C}$ lebih rendah dari pakan D. Tampaknya pakan D masih memperoleh nutrien esensial (selain protein dan energi) dari bahan pakan D (tepung ikan, tepung kedelai, dan dedak) dalam jumlah terbatas untuk menghasilkan pertambahan bobot rata-rata terbatas pula. Tepung ikan, tepung kedelai, dan dedak secara bersama mengandung asam lemak esensial, mineral, dan vitamin (Lovell, 1988; NRC, 1983).

Pakan komersial E dan F yang mempunyai kadar protein sama dan tertinggi di antara semua pakan ternyata pertambahan bobot rata-ratanya lebih rendah dari pakan yang kadar proteinnya jauh lebih rendah bahkan pertambahan bobot rata-rata pakan $\mathrm{F}$ terendah. Ini berarti dalam $E$ dan $F$ terdapat faktor bukan kadar protein yang menurunkan pertambahan bobot rata-rata. Formulasi kedua pakan komersial ini tidak diketahui.

\section{Nilai Konversi Pakan}

Di antara pakan laboratorium A, B, C, dan D; pakan A mempunyai nilai konversi pakan terendah $(P<0,05)$ atau efisiensi pakan tertinggi (Tabel 2). Urutan mutu pakan berdasarkan efisiensi pakan dari yang tertinggi ke yang terendah adalah (yang dalam kurung tak berbeda nyata): A, B (C,D). Urutan pakan ini sama dengan urutan pakan berdasarkan pertambahan bobot rata-rata benih seperti dibahas di muka. Hal ini karena definisi efisiensi pakan atau nilai konversi pakan terkait dengan pertambahan bobot rata-rata. Pakan komersial $E$ lebih efisien $(P<0,05)$ dari $F$. Dibanding pakan komersial maka urutan pakan laboratorium adalah $(A, E) ;(B, E) ;(C, D, F)$ (Tabel 2).

Efisiensi pakan antara lain tergantung pada kecukupan nutrien dan energi pakan. Ketidakcukupan nutrien, energi terlalu tinggi atau terlalu rendah akan menurunkan laju pertambahan bobot rata-rata (Lovell, 1988; NCR, 1983). Bila mutu pakan rendah, kebutuhan pakan untuk perawatan (sebelum ada pertambahan bobot rata-rata) dan untuk pertambahan bobot rata-rata meningkat sehingga efisiensi pakan menurun. Rendahnya energi pakan menyebabkan ikan giat makan untuk memenuhi kebutuhan energinya dan 
Tabel 2. Nilai konversi pakan oleh benih setelah 53 hari pemberian pakan dengan jatah pakan harian $10-6 \%$ dari bobot benih

Table 2. Means of the feed conversion ratios by the fish after 53 days of feeding at daily feeding rates of 10$6 \%$ of fish body weight

\begin{tabular}{cc}
\hline $\begin{array}{c}\text { Pakan } \\
\text { Diets }\end{array}$ & $\begin{array}{c}\text { Nilai konversi pakan * } \\
\text { Feed conversion ratio }\end{array}$ \\
\hline A & $1.70 \pm 0.13^{\mathrm{a} * *}$ \\
B & $3.12 \pm 0.65^{\mathrm{b}}$ \\
C & $5.0 .9 \pm 0.53^{\mathrm{c}}$ \\
D & $5.60 \pm 1.57^{\mathrm{c}}$ \\
E & $2.68 \pm 0.15^{\mathrm{ab}}$ \\
F & $5.30 \pm 0.19^{\mathrm{C}}$ \\
\hline
\end{tabular}

* Nilai rataan dan simpangan baku (Mean and standard deviation)

** Nilai dalam kolom yang sama dan diikuti oleh huruf yang sama tidak berbeda nyata $(P>0,01)$

Value in columns followed by the same superscript are not significantly different $(P>0.01)$

mungkin tetap lapar walaupun jumlah pakan banyak (Hoar et al.,1979). Rendahnya kadar nutrien pakan esensial dan energi (dengan nilai konversi pakan 5,60) terlihat mencolok dibandingkan pakan B (nilai konversi pakan 3,12). Nampak pula bahwa pakan komersial terutama $\mathrm{F}$ mungkin faktor lain dari kadar protein yang menyebabkan rendahnya efisiensi pakan meskipun kadar proteinnya tinggi (Lampiran 2).

Nilai konversi pakan dalam percobaan ini belum mewakili nilai konversi pakan optimal karena jumlah pakan harian (19\%-6\% dari bobot benih ikan/hari) bukan jumlah optimal. Tetapi nilai konversi pakan $\mathrm{A}$ $(1,70)$ tampaknya cukup baik. Di kalangan pembudi daya lele Amerika Ichtalurus punctatus (jenis iklim panas) ada anggapan bahwa nilai konversi pakan 1,70 menunjukkan kecukupan energi pakan (NRC, 1983). Schmittou (1989) mengajukan nilai konversi pakan 1,5 bagi pakan ikan mas bermutu tinggi dengan $32 \%$ protein untuk pembesaran dari ukuran $15 \mathrm{~g}$ menjadi 500 $\mathrm{g}$ dalam keramba jaring apung. Bagi pakan A diperkirakan nilai konversi pakan 1,5 bila jumlah pakan harian $7 \%$ /hari dan 1,3 bila jumlah pakan $6 \%$ /hari. Tampak bahwa nilai konversi pakan terbaik pakan $\mathrm{A}$ (kurang dari 1,7) mungkin tercapai dengan pemberian jumlah pakan harian optimal.

\section{Kadar Protein dan Komposisi Proksimat Tubuh Benih Lele}

Pertumbuhan berarti terbentuknya bahan struktural tubuh yang tercermin pada komposisi proksimat tubuh dan tidak meliputi bahan yang bersifat cadangan seperti lemak dan karbohidrat sebagai cadangan energi yang disimpan tubuh (Lagler et al.,1977). Porsi lemak dan karbohidrat sebagai cadangan energi tak dapat diketahui dari data komposisi proksimat tubuh. Secara kuantitatif, yang merupakan produk langsung proses pertumbuhan adalah pembesaran protein tubuh yang terbentuk terutama dalam pembentukan dan pernbesaran sel-sel tubuh dan abu tubuh yang terbentuk terutama dalam pembentukan kerangka tubuh. Namun demikian pertumbuhan memerlukan peran mutlak energi (lemak, karbohidrat) dan nutrien esensial lain dari pakan. Air diperoleh ikan dari lingkungan tetapi secara terkontrol antara lain dalam kaitan dengan osmoregulasi (Lagler et al.,1977; Stickney, 1979; Chow, 1980; Lovell, 1988; Clark, 1989). Kadar abu tubuh juga diparalel terkontrol dalam rangka hemeostasis (Shearer, 1994) dan perubahan kadar air tubuh umumnya berlawanan arah dengan perubahan kadar lemak tubuh seperti dikemukakan Lagler et al. (1977) dan Shearer (1994). Hewan mempunyai sistem terkontrol terhadap berlangsungnya proses pertumbuhan secara terkoordinasi dan terintegrasi (Strand, 1976). Dengan demikian, variasi komposisi proksimat tubuh benih mungkin tak sepenuhnya sesuai dengan variasi komposisi pakan. Kadar protein tubuh dan abu tubuh merupakan parameter utama adanya pertumbuhan ikan, sedangkan komponen proksimat lain namun sebagai pendukung. Hasil evaluasi beda nyata komposisi proksimat antar pakan laboratorium A, B, $C, D$, dan komersial $E, F$ (Lampiran 5 dan 6) menunjukkan urutan pengaruh pakan sebagai berikut (berbeda nyata pada taraf $5 \%$ ):

a. Urutan kemampuan pakan laboratorium dalam menghasilkan protein tubuh dari yang tertinggi sampai terendah: A, D, pasangan pakan lain tak berbeda nyata. Dalam perbandingan dengan pakan komersial: $(A, C, E, F)(B, D)$.

b. Urutan kemampuan pakan laboratorium menghasilkan abu tubuh dari yang tertinggi ke yang rendah: $(A, C) ;(B, D)$. Dalam perbandingan 
dengan pakan komersial: (A,C,E,F); (B,D).

C. Urutan kemampuan pakan laboratorium menghasilkan lemak tubuh dari yang tinggi ke yang rendah: $(A, B) ;(C, D)$. Dalam perbandingan dengan pakan komersial : $(A, C, E, F) ;(B, D)$.

d. Urutan pengaruh pakan laboratorium terhadap kadar air tubuh dari yang rendah ke yang tinggi:

A, D pasangan pakan lain tak berbeda nyata. Dalam perbandingan dengan pakan komersial $(A, C, E, F)$; $(B, D)$.

e. Pengaruh pakan terhadap karbohidrat tubuh $(A, B, C, D, E, F)$.

Dalam pembahasan pertambahan bobot rata-rata dan nilai konversi pakan telah disimpulkan bahwa urutan kemampuan pakan laboratorium menghasilkan pertambahan bobot rata-rata maupun urutan efisiensi pakan dari yang tinggi ke yang rendah (atau dari nilai konversi pakan rendah ke yang tinggi) adalah sama yakni: A, B, (C,D). Sedangkan dibanding pakan komersial untuk pertambahan bobot rata-rata: $A, B$; $(B, E) ;(C, E) ;(D, F)$; dan untuk efisiensi pakan: $A$; $(B, E) ;(C, D, F)$. Tampak bahwa urutan pakan dalam menghasilkan pertambahan bobot rata-rata tidak persis sama dengan urutan dalam menghasilkan komponen proksimat tubuh. Namun tampak bahwa pertambahan bobot rata-rata tertinggi dari pakan lengkap A (dengan kadar protein optimal) diikuti kadar protein tubuh, abu tubuh, lemak tubuh, dan karbohidrat tubuh yang lebih tinggi atau berbeda nyata dengan kelima pakan lain dan kadar air tubuh, yang tidak berbeda nyata atau lebih rendah dari yang lain. Sebaliknya pertambahan bobot rata-rata terendah dari pakan D (kadar protein cukup tinggi tetapi kadar nutrien esensial rendah, energi relatif rendah) diikuti protein tubuh, abu tubuh, lemak tubuh, dan karbohidrat tubuh lebih rendah atau tak berbeda nyata dari pakan lain dan hanya kadar air tubuh tertinggi. Tampak pula dari perbandingan pakan $\mathrm{B}$ dan $\mathrm{D}$ bahwa peniadaan bahan minyak essensial, mineral, vitamin (serta pengurangan energi) dari formulasi pakan $D$ menurunkan pertambahan bobot rata-rata, efisiensi pakan, kadar lemak tubuh, dan meningkatkan kadar air tubuh, tetapi tidak dengan nyata $(P>0,05)$ mengubah kadar protein tubuh, abu tubuh, dan karbohidrat tubuh. Ini berarti bahwa nutrien esensial yang tidak ditambahkan dalam formulasi pakan $D$ masih diperoleh dalam jumlah terbatas dari tepung ikan, tepung kedelai, dan dedak. Ketiga bahan ini secara bersama mengandung mineral, minyak esensial, dan vitamin tertentu (Lovell, 1988; NRC, 1983; Davis \& Gatlin, 1991; Tacon, 1991; Lim \& Dominy, 1989). Keterbatasan kadar nutrien esensial dan rendahnya energi pakan $\mathrm{D}$ berpengaruh cukup mencolok yang menyebabkan pertambahan bobot rata-rata tidak berbeda nyata dari pakan $\mathrm{C}$ yang kadar proteinnya lebih rendah dan kadar energinya lebih tinggi dari pakan $\mathrm{D}$.

Pakan $\mathrm{C}$ menghasilkan kadar lebih tinggi dari pakan B meskipun kadar protein pakan C lebih rendah. Ini mungkin karena perbandingan energi dan protein pakan C (Lampiran 1) lebih mendekati nilai optimal sekitar $9,6 \mathrm{kcal} / \mathrm{g}$ protein untuk pembentukan protein tubuh (Rabegnatar et al.,1992). Dalam pakan A peran kadar protein dan energi yang cukup tinggi tampaknya menonjol sehingga kadar protein tubuhnya juga tinggi.

Kadar air tubuh tertınggi pada pakan D sesuai dengan pengamatan umum bahwa rendahnya kadar lemak tubuh diikuti oleh tingginya kadar air tubuh (dibanding pakan B). Pakan lainnya tidak begitu berbeda dalam hal kadar energi (Tabel 1) tetapi lebih tinggi dari pakan D. Tampaknya peran kadar energi ini cukup menonjol sehingga kadar air tubuh antara pakan lain tidak berbeda nyata dan lebih rendah dari pakan D.

Kadar karbohidrat tubuh yang tak berbeda nyata antar semua pakan tempaknya karena ikan umumnya hanya dapat memanfaatkan karbohidrat dalam jumlah terbatas. Ikan iklim panas lebih mampu memanfaatkan karbohidrat dibanding ikan iklim dingin (Lovell, 1988); sehingga kadar karbohidrat tubuh tak begitu berbeda walaupun kadar karbohidrat komposisi pakan bervariasi.

Semua komposisi proksimat benih lele diatas adalah komposisi yang mengandung pertumbuhan benih dengan fisik normal.

\section{Formulasi Pakan Terbaik}

Formulasi pakan terbaik adalah formulasi yang menghasilkan pakan dengan mutu terbaik berdasar kriteria: pertambahan bobot rata-rata tinggi, kadar protein tubuh tinggi, dan efisiensi tinggi (nilai konversi pakan rendah). Berdasarkan bahasan mengenai kemampuan pakan berdasar kriteria ini dapat disimpulkan urutan mutu formulasi pakan laboratorium dan perbandingan dengan kedua pakan komersial seperti kesimpulan di bawah ini.

\section{KESIMPULAN}

1. Berdasarkan pertambahan bobot rata-rata benih lele, kadar protein tubuh benih, dan nilai konversi pakan atau efisiensi pakan sebagai kriteria mutu pakan, maka formulasi pakan lengkap A merupakan formulasi yang mempunyai mutu tertinggi. Pada kondisi percobaan, pakan A mempunyai pertambahan bobot rata-rata $10,56 \%$ / hari; nilai konversi pakan 1,70; dan kadar protein tubuh $14,34 \%$ 
2. Dibanding kedua pakan komersial, maka: a) mutu pakan $B$ lebih baik $(P<0,05)$ atau tidak berbeda nyata dalam hal pertambahan bobot rata-rata $(5,41 \%$ /hari) dan efisiensi pakan (nilai konversi pakan 3,12 ) tetapi lebih rendah dalam hal kadar protein tubuh (13,62\%); b) mutu pakan D tidak berbeda nyata dalam pertambahan bobot rata-rata (3,46\%/hari) dan kadar protein tubuh (14,00\%) tetapi lebih rendah dalam hal efisiensi pakan (nilai konversi pakan 5.09 ); c) mutu pakan D tidak berbeda nyata atau lebih rendah dalam hal pertambahan bobot rata-rata $(2,96 \% /$ hari $)$, dan efisiensi pakan (nilai konversi pakan 5.60) serta kadar protein tubuh (13,39\%).

3. Sintasan benih lele yang diamati pada pakan $A$ $(83,3 \%)$ tidak berbeda nyata $(P>0,05)$ dengan pakan komersial (99,3-100\%); sintasan pada B, C, D $(50,7-71,3 \%)$ lebih rendah dari pakan komersial. Tetapi kematian benih tidak disebabkan oleh pengaruh pakan (sebagai nutrien) melainkan oleh perubahan sekunder terhadap pakan yang menimbulkan amonia tidak terionisasi $\left(\mathrm{NH}_{3}\right)$ yang bersifat racun dalam air media budi daya. Hal ini dalam praktek dapat diminimalkan sehingga tidak mengganggu benih lele.

\section{UCAPAN TERIMA KASIH}

Penulis mengucapkan terima kasih kepada Saudari Ati Puspitasari (teknisi litkayasa) atas bantuannya dalam melakukan analisis proksimat bahan pakan, pelet, dan benih lele.

\section{DAFTAR PUSTAKA}

Akiyama, D.M. 1991. Soybean meal utilization by marine shrimp dalam Akiyama, D. M. and R.K.H. Tan, eds, Proc. Aq. Feed Processing and Nutrition Workshop. Thailand and Indonesia, September 19-25, 1991. ASA, Singapore. p. 207-225.

Boyd, C.E. 1979. Water Quality in Warmwater Fishponds. Auburn University, Alabama. p. 70-72.

Chow, K.W. 1980. The mineral dalam NDDP/FAO. Fish Feed Technology. Lecture presented at the FAO/ UNDP Training Cource in Fish Feed Technology held at the College of Fisheries University of Washington, Seattle, Washington, 9 October-15 December 1978. FAO, Rome. p. 104-108.

Clark, J.S. 1989. The mineral requairement of finfish (A review) dalam Akiyama, D.M. eds, Proc. People's Rep. China Aq. Feed Workshop. September, 17-30, 1989. ASA, Singapore. p. 288-302.

Davis, D.A. and D.M. Gatlin III. 1991. Dietary mineral requirement of fish and shrimp. dalam Akiyama, D.M. and R.K.H. Tan, eds. Proc. Aq. Feed Processing and Nutrition Workshop. Thailand and Indonesia, September 19-25, 1991. ASA, Singapore. p. 49-67.
Hoar, W.S.D.J. Randall, and J.R. Brett. 1979. Fish Physiology Vol. VIII. Academic Press, New York. p. 11-14.

Lagler, K.F., J.E. Bardach, R.R Miller, and D.R.M. Passino 1977. Ichtyology, $2^{\text {nd }}$ ed, John Wiley and Sons, New York. p. 153-163.

Lim, C. and W. Dominy. 1989. Utilization of pakan proteins by warmwater fish dalam Akiyama, D.M. and R.K.H.Tan, eds. Proc. Aq. Feed Processing and Nutrition Workshop. Thailand and Indonesia, September 19-25, 1991. ASA, Singapore. p. 163-172.

Lovell, T. 1988. Nutrition and Feeding of Fish, Van Nostrand Reinhold, New York. p. 63-64; 111-114; 243253.

NRC (National Research Council). 1983. Nutrient Requirements of Warmwater Fishes and Shellfishes. National Academy of Sciences Washington, D.C. p. 76-80.

Rabegnatar, I.N.S., W. Hidayat, dan Sumastri, S. 1990. Penelitian pendahuluan: pertumbuhan maksimal dan kelangsungan hidup benih lele (Clarias batrachus) yang diberi pakan buatan dalam kondisi laboratorium. Bull. Penel. Perik. Darat. 9(2): 118-134.

Rabegnatar, I.N.S., W. Hidayat, dan Sumastri, S. 1991a. Pengaruh tambahan vitamin dalam pakan terhadap tingkat kelangsungan hidup dan pertumbuhan benih lele (Clarias batrachus) dengan penggantian air media tiap hari dan dua hari dalam kondisi laboratorium. Bull. Penel. Perik. Darat. 10(1): 89-107.

Rabegnatar, I.N.S., W. Hidayat, dan Sumastri, S. 1991b. Kadar optimal tambahan vitamin dalam pakan buatan untuk peningkatan kelangsungan hidup dan pertumbuhan lele (Clarias batrachus) dalam budi daya keramba jaring apung di Danau Lido, Bogor. Bull. Penel. Perik. Darat. 10 (2): 81-103.

Rabegnatar, I.N.S. dan W. Hidayat. 1992. Estimasi kadar perbandingan optimal energi dan protein pakan buatan untuk pembesaran benih lele (Clarias batrachus) dalam keramba jaring apung. Bull. Penel. Perik. Darat. 11(2): 151-167.

Rabegnatar, I.N.S. dan O. Praseno. 1993. Estimasi kadar protein optimal dalam pakan buatan untuk pembesaran benih lele (Clarias batrachus) dalam keramba jaring apung. Bull. Penel. Perik. Darat. 12 (1): 86-112.

Rabegnatar, I.N.S. dan S. Asih. 1995. Estimasi perbandingan optimal kadar protein tepung ikan dan protein tepung kedele dalam pakan untuk benih lele (Clarias batrachus). Pros. Sem. Hasil Penel. Balai Penel. Perik. Air Tawar 1994/1995. Balai Penel. Perik. Air Tawar, Sukamandi. p. 208-215.

Schmittou, H.R. 1989. Guidlines for raising principally omnivorous carps, catfish and tilapias in cages suspended in freshwater ponds, lakes, and reservoirs, dalam Akiyama, D.M. ed Proc. People's Rep. China Aq. Feed Workshop, September 17-30. ASA, Singapore. p. 24-42.

Shearer, K.D. 1994. Factor Affecting the proximate composition of cultured fished with emphasis on salmonids. Aquaculture, 119: 63-88. 
Shell, E.W. 1983. Fish Farming Research. Auburn, Alabama, Auburn University. p. 51-53.

Sokal R.R. and F.J. Rohlf. 1973 Introduction to Bio statistic, W. H. Freeman and Company, San Fransisco. p. 208-217.

Steel, R.G.D. and J.H. Torrie. 1960. Principle and Procedures of Statistics with Special Reference to the Biologycal Sciences. Mcgrw-Hill Book Company, Inc., New York. p. 107-109.

Stickney, R.A. 1979. Principles of Warmwater Aquaculture. John Wiley and Sons, New York. p. 181-183.
Strand, F.L. 1976. Physiology. A regulatory system approach. Macmillan Publishing Co., Inc. New York. p. 3-61.

Suhenda, N. 1988. Pertumbuhan benih ikan lele (Clarias batrachus) yang mendapat ransum dengan kadar protein dan energi berbeda. Bull. Penel. Perik. Darat. 7(2): 16-23.

Tacon, A.G.J. 1991. Vitamin nutrition in shrimp and fish, dalam Akiyama, D.M. and R.K.H. Tan. Proc. Aw. Feed Processing and Nutrition Workshop. Thailand and Indonesia, September 19-25, 1991. ASA, Singapore. p. 10-41. 
Lampiran 1. Komposisi pakan jenis laboratorium: A (45\% protein, lengkap); B (40\% protein, lengkap); C ( $35 \%$ protein, lengkap); dan D ( $40 \%$ protein, tak lengkap)

Appendix 1. Formulation of the laboratory prepared diets: $A$ (45\% protein, complete diet); B (40\% protein, complete diet); C (35\% protein, complete diet); and D (40\% protein, incomplete diet)

\begin{tabular}{|c|c|c|c|c|}
\hline \multirow[t]{2}{*}{$\begin{array}{l}\text { Bahan Pakan } \\
\text { Feed ingredients }\end{array}$} & \multicolumn{4}{|c|}{$\begin{array}{l}\text { Kadar (\% dari campuran } \\
\text { Levels (\% of feed mixture) }\end{array}$} \\
\hline & $\mathbf{A}$ & B & C & $\mathbf{D}$ \\
\hline Tepung ikan (fish meal) $(56,48 \%$ protein) & 61.44 & 51.2 & 43.006 & 51.2 \\
\hline Tepung kedelai (soybean meal) ( $44,74 \%$ protein) & 23.02 & 19.18 & 16.115 & 19.18 \\
\hline Dedak (rice bran) $(12,86 \%$ protein) & 0 & 19.44 & 27.25 & 19.44 \\
\hline \multicolumn{5}{|l|}{ Minyak (oils) : } \\
\hline Minyak ikan (fish oil) & 0 & 0.15 & 0.69 & 0 \\
\hline Minyak jagung (com oil) & 2.5 & 2.5 & 2.5 & 0 \\
\hline Minyak kelapa (coconut oil) & 5.05 & 1.5 & 3.24 & 0 \\
\hline \multicolumn{5}{|l|}{ Mineral (minerals): } \\
\hline Dikalsium fosfat (dicalcium phosphate) & 4 & 2.73 & 3,449 & 0 \\
\hline Campuran mineral * (mineral mix) & 0.25 & 0.1 & 0.2 & 0 \\
\hline Garam beriodium (iodized table salt) & 0.25 & 0.1 & 0.25 & 0 \\
\hline Magnesium sulfat (magnesium sulfate) & 0.45 & 0.1 & 0.25 & 0 \\
\hline Kalsium karbonat (calcium carbonate) & 0.15 & 0.1 & 0.15 & 0 \\
\hline Campuran vitamin ${ }^{\star \star}($ vitamin mix) & 1 & 1 & 1 & 0 \\
\hline Vitamin C (vitamin C) & 0.4 & 0.4 & 0.4 & 0 \\
\hline Perekat CMC (binder, $C M C)$ & 1.5 & 1.5 & 1.5 & 1.5 \\
\hline \multicolumn{5}{|l|}{ Bahan bukan nutrien (non nutrient materia/): } \\
\hline Avicel (avicel) & 0 & 0 & 0 & 8.68 \\
\hline Total & 100 & 100 & 100 & 100 \\
\hline \multicolumn{5}{|l|}{ Data terhitung (calculated data): } \\
\hline Kadar protein (protein level) & 45 & 40 & 35 & 40 \\
\hline \multirow{2}{*}{\multicolumn{5}{|c|}{$\begin{array}{l}\text { Energi metabolisme (metabolizable energy) (kkal/ } 100 \mathrm{~g} \text { feed) } \\
\text { Perbandingan enerai dan protein (enerav to protein ratio) }\end{array}$}} \\
\hline Perbandingan energi dan protein (energy to protein & & & & \\
\hline Lemak total (total fat) & 12.08 & 10 & 12.5 & 5.85 \\
\hline Minyak ikan (fish oil) & 4.02 & 3.5 & 3.5 & 3.35 \\
\hline Minyak kedelai (soybean oil) & 0.52 & 0.43 & 0.36 & 0.43 \\
\hline Minyak jagung (corn oil) & 2.5 & 2.5 & 2.5 & 0 \\
\hline Minyak kelapa (coconut oil) & 5.04 & 3.57 & 6.14 & 2.07 \\
\hline Karbohidrat (carbohydrate) & 14.47 & 22.81 & 25.2 & 22.81 \\
\hline Serat kasar (crude fibre) & 2.22 & 2.43 & 2.35 & 2.43 \\
\hline Abu (ash) & 18.36 & 16.35 & 17.23 & 13.22 \\
\hline
\end{tabular}




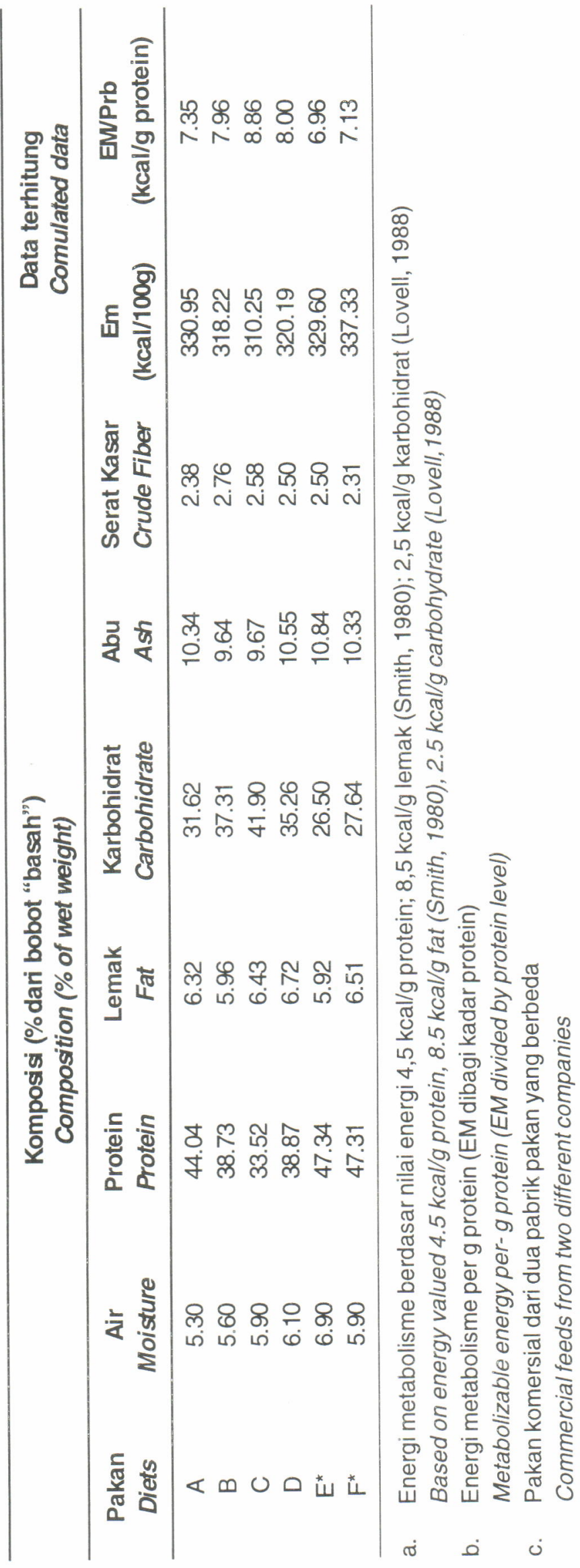


Lampiran 3. Komposisi campuran mineral pakan percobaan A, B, C

Appendix 3. Composition of mineral mix for the experimental diets $A, B, C$

\begin{tabular}{|c|c|}
\hline $\begin{array}{l}\text { Bahan mineral } \\
\text { Mineral compounds }\end{array}$ & $\begin{array}{l}\text { Kadar }(g / 1.000 \mathrm{~g}) \\
\text { Levels }(g / 1,000 \mathrm{~g})\end{array}$ \\
\hline $\mathrm{MnSO}_{4} \cdot \mathrm{H}_{2} \mathrm{O}$ & 147.6704 \\
\hline $\mathrm{ZnSO}_{4} \cdot 7 \mathrm{H}_{2} \mathrm{O}$ & 202.3374 \\
\hline $\mathrm{FeSO}_{4} \cdot 7 \mathrm{H}_{2} \mathrm{O}$ & 79.6508 \\
\hline $\mathrm{CuSO}_{4} \cdot 5 \mathrm{H}_{2} \mathrm{O}$ & 7.8584 \\
\hline $\mathrm{KIO}_{3}$ & 1.6864 \\
\hline $\mathrm{CoCl}_{2} .6 \mathrm{H}_{2} \mathrm{O}$ & 1.2461 \\
\hline $\mathrm{Na}_{2} \mathrm{SeO}_{3} \cdot 5 \mathrm{H}_{2} \mathrm{O}$ & 0.1217 \\
\hline Bahan baku nutrien (Avicel) & 559.4288 \\
\hline Total & 1,000 \\
\hline
\end{tabular}

Disusun berdasar anjuran NRC (1977), Lovell (1988)

Formulated on pasis of suggestions in NRC (1977), Lovell (1988)

Lampiran 4. Komposisi Campuran Vitamin Pakan Percobaan A, B, C

Appendix 4. Composition of vitamin mix for the experimental diets $A, B, C$

\begin{tabular}{|c|c|}
\hline $\begin{array}{l}\text { Vitamin dan bahan } \\
\text { Vitamins and non nutrient }\end{array}$ & $\begin{array}{l}\text { Kadar }(g / 1000 \mathrm{~g}) \\
\text { Levels }(g / 1000 \mathrm{~g})\end{array}$ \\
\hline Vitamin $A$ dan $D_{3}\left(\right.$ Vitamin $A$ and $\left.D_{3}\right)\left(5 \times 105\right.$ I.U. vitamin $A$ dan 105 Vitamin $\left.D_{3} / g\right)$ & 8.8 \\
\hline Vitamin E (Vitamin E) & 22 \\
\hline Vitamin $\mathrm{K}($ Vitamin K) & 4.4 \\
\hline Choline chloride (Choline chloride) & 220 \\
\hline Niacin (Niacin) & 40 \\
\hline Riboflavin (Riboflavin) & 8 \\
\hline Pyridoxine (Pyridoxin) & 8 \\
\hline Thiamin (Thiamin) & 8 \\
\hline Dikalsium pantothenat (Dicalcium panthotenate) & 20 \\
\hline Biotin (Biotin) $2 \%$ & 2 \\
\hline Folacin (Folacin) & 2 \\
\hline Inositol (Inositol) & 0.8 \\
\hline Bahan baku nutrien (Non nutrient material) (cellulose) "Avicel" & 40 \\
\hline
\end{tabular}

*Disusun berdasar informasi Dopree (1977), Robinson (1985), Lovell (1988), dan Rabegnatar et al. (1991)

*Formulated on basis of information in Dupree (1977), Robinson (1985), and Rabegnatar et al. (1991) 
Lampiran 5. Komposisi proksimat tubuh benih pada awal percobaan (sebelum pemberian pakan) Appendix 5. Initial proximate composition of the fish body (prior to feeding)

\begin{tabular}{lr}
\hline \multicolumn{1}{c}{$\begin{array}{c}\text { Komponen proksimat } \\
\text { Component }\end{array}$} & $\begin{array}{c}\text { Kadar (\% dari bobot "basah") } \\
\text { Levels (\% of wet weight) }\end{array}$ \\
\hline Air (Moisture) & 76.97 \\
Protein (Protein) & 12.13 \\
Lemak (Fat) & 2.72 \\
Karbohidrat (Bahan Ekstrak Tanpa Nitrogen) & \\
Carbohydrate (Nitrogen Free Extract) & 5.65 \\
Abu (Ash) & 2.00 \\
Serat kasar (Crude fibre) & 0.53 \\
\hline \multicolumn{1}{c}{ Total } & 100 \\
\hline
\end{tabular}

Lampiran 6. Komposisi proksimat tubuh benih setelah 53 hari pemberian pakan Appendix 6. Proximate composition of the fish body after 53 days of feeding

\begin{tabular}{ccccccc}
\hline $\begin{array}{c}\text { Pakan } \\
\text { Diets }\end{array}$ & $\begin{array}{c}\text { Air * } \\
\text { Moisture }\end{array}$ & $\begin{array}{c}\text { Protein } \\
\text { Protein }\end{array}$ & $\begin{array}{c}\text { Lemak } \\
\text { Fat }\end{array}$ & $\begin{array}{c}\text { Karbohidrat } \\
\text { Carbohydrate }\end{array}$ & $\begin{array}{c}\text { Abu } \\
\text { Ash }\end{array}$ & $\begin{array}{c}\text { Serat Kasar } \\
\text { Crude fibre }\end{array}$ \\
\hline A & $73.88^{\mathrm{a} * *} \pm 0.26$ & $14.34^{\mathrm{ab}} \pm 0.14$ & $4.35^{\mathrm{a}} \pm 0.04$ & $3.99^{\mathrm{a}} \pm 0.01$ & $2.73^{\mathrm{a}} \pm 0.15$ & $0.17^{\mathrm{ab}} \pm 0.03$ \\
B & $74.87^{\mathrm{a}} \pm 0.86$ & $13.62^{\mathrm{a}} \pm 0.60$ & $4.23^{\mathrm{a}} \pm 0.22$ & $4.15^{\mathrm{a}} \pm 0.14$ & $2.48^{\mathrm{a}} \pm 0.08$ & $0.66^{\mathrm{ac}} \pm 0.03$ \\
C & $74.58^{\mathrm{ab}} \pm 0.91$ & $14.00^{\mathrm{ac}} \pm 0.53$ & $3.77^{\mathrm{bc}} \pm 0.12$ & $4.32^{\mathrm{a}} \pm 0.34$ & $2.66^{\mathrm{a}} \pm 0.04$ & $0.66^{\mathrm{ac}} \pm 0.04$ \\
D & $75.70^{\mathrm{a}} \pm 0.59$ & $13.39^{\mathrm{c}} \pm 0.45$ & $3.91^{\mathrm{cd}} \pm 0.12$ & $3.98^{\mathrm{a}} \pm 0.13$ & $2.34^{\mathrm{c}} \pm 0.08$ & $0.68^{\mathrm{abc}} \pm 0.03$ \\
E & $74.11^{\mathrm{a}} \pm 1.06$ & $14.07^{\mathrm{ac}} \pm 0.45$ & $4.25^{\mathrm{a}} \pm 0.27$ & $4.22^{\mathrm{a}} \pm 0.32$ & $2.71^{\mathrm{a}} \pm 0.11$ & $0.64^{\mathrm{c}} \pm 0.04$ \\
F & $73.56^{\mathrm{a}} \pm 0.51$ & $14.80^{\mathrm{a}} \pm 0.36$ & $4.13^{\mathrm{ad}} \pm 0.08$ & $4.05^{\mathrm{a}} \pm 0.32$ & $2.72^{\mathrm{a}} \pm 0.11$ & $0.74^{\mathrm{b}} \pm 0.03$ \\
\hline
\end{tabular}

* Nilai rataan dan simpangan baku (Mean and standard deviation)

**Nilai dalam kolom yang sama dan diikuti oleh huruf yang sama tidak berbeda nyata $(P>0,01)$

Value in columns followed by the same superscript are not significantly different $(P>0.01)$ 


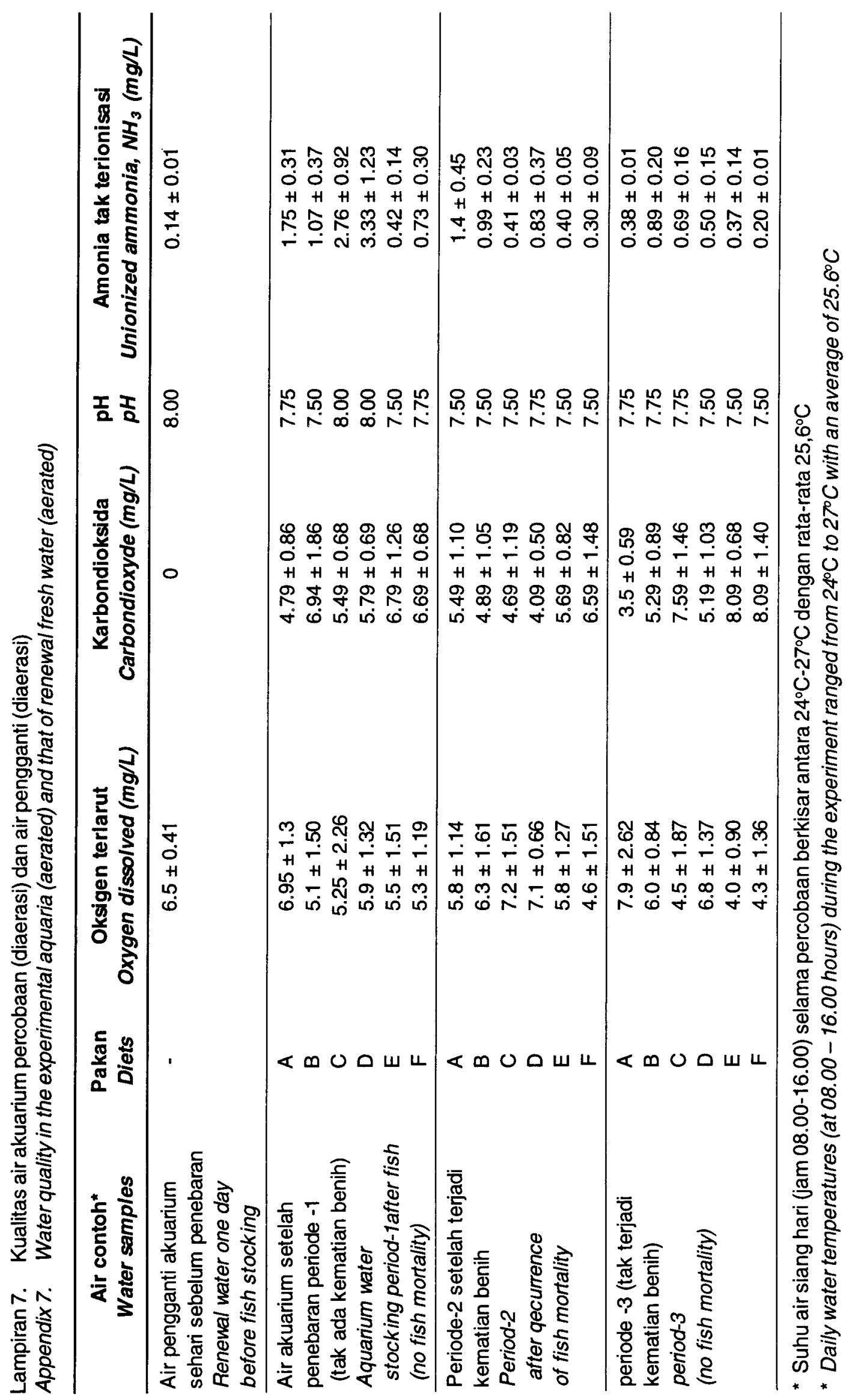

